\title{
Journal of Forensic Sciences
}

\section{Contents}

\section{Letter to the Editor}

Erratum for "Representative Sampling of Drug Seizures in Multiple

Containers" - SIDNEY W. HINKLEY

\section{Main Articles}

Validation Studies on the Analysis of the HLA DQ $\alpha$ Locus Using the Polymerase Chain Reaction-CATHERINE THEISEN COMEY AND BRUCE BUDOWLE 1633

Typing of Deoxyribonucleic Acid (DNA) Extracted from Compact Bone from Human Remains-MANFRED N. HOCHMEISTER, BRUCE BUDOWLE, URS V. BORER, URS EGGMANN, CATHERINE T. COMEY, AND RICHARD DIRNHOFER

A Rapid Method for the Determination of Cocaine in Brain Tissue-SUSAN P. BROWNE, CHRISTINE M. MOORE, JOANNE SCHEURER, IAN R. TEBBETT, AND BARRY K. LOGAN

Isolation, Identification, and Origin of Three Previously Unknown Congeners in Illicit Cocaine-JAAP G. ENSING AND JAN C. HUMMELEN

Clinical and Morphological Findings on Mustard Gas [Bis(2-Chloroethyl)Sulfide] Poisoning - WOLFGang EISENMENGER, GUSTAV DRASCH, MAX VON CLARMANN, ELISABETH KRETSCHMER, AND GABRIELE ROIDER

Fiber Transfer and the Influence of Fabric Softener-RANDALL R. BRESEE AND PATRICIA A. ANNIS

Arson Evidence Container Evaluation: II. "New Generation" Kapak BagsWILLIAM D. KINARD AND CHARLES R. MIDKIFF, JR.

Geriatric Offenders Examined at a Forensic Psychiatry Clinic-RICHARD ROSNER, MELVIN WIEDERLIGHT, RONNIE B. HARMON, AND DAVID J. CAHN

\section{Technical Notes}

Cocaine in Decomposed Human Remains-DION T. MANHOFF, IAN HOOD, FRANK CAPUTO, JEFFREY PERRY, SAMUEL ROSEN, AND HARESH G. MIRCHANDANI

Matching Bullets to Bone Impact Signatures-o'BRIAN C. SMITH, STEVEN A. SYMES, HUGH E. BERRYMAN, AND MARK A. LEVAUGHN 


\section{Case Reports}

Fetal Death Following Maternal Trauma: Two Case Reports and a Survey of the Literature-BARRY D. LIFSHULTZ AND EDMUND R. DONOGHUE

Detection of Bone and Bone-Plus-Bullet Particles in Backspatter from CloseRange Shots to Heads-BRYAN R. BURNETT

Autoerotic Asphyxial Death Initially Misinterpreted as Suicide and a Review of the Literature-JOSÉ ALBERTO GARZA-LEAL AND FRANCISCO J. LANDRÓN

Cardiac Laceration and Pericardial Tamponade Due to Cardiopulmonary

Resuscitation After Myocardial Infarction-AMY E. NOFFSINGER, KAREN

S. BLISARD, AND M. GREGORY BALKO

Identification of Human Remains by Comparison of Frontal Sinus Radiographs:

A Series of Four Cases-DONNELl C. MARLIN, MICHAEL A. CLARK, AND

S. MILES STANDISH

\section{Book Review}

Witnesses from the Grave: The Stories Bones Tell (Joyce and Stover)-WILliam B. SULLIVAN, JR.

Indexes to Volume 36 of the Journal of Forensic Sciences

Editorial Communications (Information for Authors)

Published bimonthly by ASTM

1916 Race Street, Philadelphia, PA 19103 


\author{
Wolfgang Eisenmenger, ${ }^{1}$ M.D.; Gustav Drasch, ${ }^{1}$ Ph.D.; \\ Max von Clarmann, ${ }^{2}$ M.D.; Elisabeth Kretschmer, ${ }^{1}$ M.Pharm.; \\ and Gabriele Roider, ${ }^{1}$ M.Pharm.
}

\title{
Clinical and Morphological Findings on Mustard Gas [Bis(2-Chloroethyl)Sulfide] Poisoning
}

\begin{abstract}
REFERENCE: Eisenmenger, W., Drasch, G., von Clarmann, M., Kretschmer, E., and Roider, G., "Clinical and Morphological Findings on Mustard Gas [Bis(2-Chloroethyl)Sulfide] Poisoning," Journal of Forensic Sciences, JFSCA, Vol. 36, No. 6, Nov. 1991, pp. 1688-1698.

ABSTRACT: In 1984 and 1985, a total of eleven Iranian patients were transferred to hospitals in Munich, Germany, after a reported gas attack in the Iran-Iraq war. The initial symptoms and pretreatment in Teheran, Iran, as well as the admittance examination data, the clinical courses of the patients, and the clinical laboratory data in Germany, are reported. The main injuries were to the skin, the eyes, and the respiratory tract. One patient stopped breathing suddenly on the third day of treatment (eight days after the exposure). A large piece of mucous membrane blocking a bronchus was removed during an immediate bronchoscopy, but attempts at resuscitation failed. The most important autopsy findings in this case were severe pseudomembranous inflammation of the trachea and the bronchial tubes. The histological findings are reported. Chemical proof of the poison (mustard gas) was established. A review of the history of chemical warfare, the physical and chemical properties of mustard gas, and a literature survey of clinical findings (including, especially, experiences from World Wars I and II) contribute to the understanding of the actual cases.
\end{abstract}

KEYWORDS: pathology and biology, mustard gas, chemical warfare

\section{History of Chemical Warfare}

\section{Before World War I}

The use of chemical weapons on the battlefield has a long tradition. Even in ancient history, the historian Thucydides described how the Spartans were able to conquer the city of Delion in 424 B.C. by setting wood piles soaked in pitch and sulfur on fire and then blowing the stinging smoke toward the enemy with hollowed-out logs until the defenders had to surrender.

The development of the natural sciences at the turn of the 20th century provided the basis for medically advised militaries to imagine other target organs and other methods of transmitting chemicals into the human body. The vision of the horrible effects did, however, cause the European states to sign the Treaty of the Hague in 1899, which excluded the use of ammunition that had the sole purpose of debilitating or killing the enemy with poisonous gases.

Received for publication 7 Nov. 1987; revised manuscript received 22 Feb. 1991; accepted for publication 3 May 1991.

${ }^{1}$ Professors and assistants, respectively, Institut für Rechtsmedizin, Munich, Germany.

${ }^{2}$ Professor, Klinikum Rechts der Isar, Toxikologische Abteilung, Munich, Germany. 


\section{During World War I}

Nevertheless, in the First World War, widespread use of chemical weapons occurred; each enemy accused the other of the first break of the treaty in the "gas war."

The French were reported to have used grenades filled with bromoacetic ester, an eye irritant. As mobile warfare turned into static warfare in 1915, the demand for a means to harm the enemy in a protected position increased. Germany employed shrapnels for the first time, containing dianisidine, an irritant to the eyes and nasal passages. Further mucous membrane irritants were used in ammunition, such as xylyl bromide, monobromine acetone, and bromomethyl ketone. The British used hand grenades with carbon disulfide and hydrogen sulfide, later with mixtures of chlorine and carbon disulfide or chlorine and phosgene [1].

Since these poisons showed little effect in ammunition, the Germans first made use of a "blowing" technique in 1915 at Ypres, Belgium, where a great quantity of chlorine gas in steel cylinders was released and carried by the wind toward the enemy position [2]. Because of its enormous success, the technique was soon adopted by the British, who added chloropicrin and phosgene to the chlorine. In the next step, the blowing technique was replaced by "gas throwers." To annul or bypass the protection of gas masks (which had been developed in the meantime), chemical weapons were further developed. The first of such "mask breakers" to be used contained diphenylamine chloroarsine, diphenylarsine cyanide, and chloropicrin, with the addition of tin tetrachloride.

The complete bypass of protection by gas masks was made possible when the Germans introduced the use of dichloroethyl sulfide in 1917 at Ypres. The German code name "Lost" was derived from the names of two chemists (Lommel and Steinkopf), who were the two main contributors to the mass production of the substance [3]. The English and French named it mustard gas, after its scent, and Yperite, after the location of its first use. The simple name " $H$ " became common in English; the allied soldiers also named the substance "HS" as an abbreviation for "Hun stuff."

Mustard gas was able to damage the intact skin and penetrated practically all uniform parts. The British were motivated to obtain a similar weapon and, in turn, developed and used a comparable substance under the name Lewisite. By the end of the First World War, a multitude of chemical weapons was being used which could be roughly classified into four groups, according to their effects [4]. On the German side, the category names corresponded to the colors of crosses marked on the grenades to avoid confusion: white, blue, green, and yellow. Table 1 offers a survey of these chemical weapons and their components.

TABLE 1-Classes of chemical warfare agents.

\begin{tabular}{|c|c|c|c|}
\hline $\begin{array}{c}\text { Eye } \\
\text { Irritants } \\
\text { (White Cross) }\end{array}$ & $\begin{array}{l}\text { Nasal and Pharyngeal } \\
\text { Tract Irritants } \\
\text { (Blue Cross) }\end{array}$ & $\begin{array}{c}\text { Suffocating } \\
\text { Agents } \\
\text { (Green Cross) }\end{array}$ & $\begin{array}{c}\text { Caustic } \\
\text { Agents } \\
\text { (Yellow Cross) }\end{array}$ \\
\hline Bromoacetone & diphenylarsine chloride & chlorine & $\begin{array}{l}\text { 2-chlordiethyl } \\
\text { sulfide }\end{array}$ \\
\hline $\begin{array}{l}\text { Bromomethylethyl } \\
\text { ketone }\end{array}$ & diphenylarsine cyanide & phosgene & $\begin{array}{l}\text { ethylarsine } \\
\text { dichloride }\end{array}$ \\
\hline $\begin{array}{l}\text { Bromobenzyl } \\
\text { cyanide }\end{array}$ & diphenylamine chloroarsine & chloropicrin & $\begin{array}{l}\text { chlorovinylarsin } \\
\text { dichloride }\end{array}$ \\
\hline Chloroacetophenone & & $\begin{array}{l}\text { perchlorformic acid } \\
\text { methyl ester }\end{array}$ & $\begin{array}{c}\text { methylarsine } \\
\text { dichloride }\end{array}$ \\
\hline
\end{tabular}




\section{After World War I}

Although the use of chemical weapons was internationally proscribed after the horrible experiences in the First World War, the European powers developed new substances between the two World Wars. The best known among them included the nerve gases Tabun and Sarin [5]. Considerable quantities of these substances were produced and stored during the Second World War, but none were used.

In the Sino-Japanese War of 1937-1945, however, war gases were employed many times.

Even during the Second World War, a mass poisoning by mustard gas occurred in the European theater when a ship in the port of Bari, Italy, carrying approximately 100 tons of mustard gas exploded after a bombing from German aircraft. Six hundred people were subjected to the gas, and a considerable number of them died [6]. After 1945, many other gas poisonings occurred from contact with poorly stored mustard gas and with casks in which it was stored.

Although chemical weapons were once again internationally proscribed after the Second World War, such weapons have been further developed and produced.

\section{Chemical Warfare in the Iran-Iraq War}

It should then come as no surprise when chemical weapons are once again introduced in war conflicts.

In the Persian Gulf war between Iran and Iraq, which lasted from 1980 to 1988, Iran reported in 1982 for the first time that Iraq had introduced gas warfare. This accusation was decisively contested by Iraq. Presumably to prove its claims, Iran sent a number of such injured patients abroad after 1984 to be treated in such countries as Sweden, Austria, and the Federal Republic of Germany. In Belgium, the cause of the injuries was at first believed to be connected with arson. Now, however, there is no longer any doubt that the clinical picture was one of mustard gas poisoning.

\section{Physical and Chemical Properties of Mustard Gas}

That mustard gas is once again being employed may seem surprising at first, but is easily explained when one closely considers the particular physical and chemical properties of the substance and its effects on humans. In the First World War, mustard gas ranked as the most effective of the chemical weapons for several reasons: it was very difficult to recognize; even in small amounts, it took effect on the entire body surface; and its victims were made unfit for active duty for a long period of time.

From a physicochemical standpoint, it is of importance that 2-chlorodiethyl sulfide evaporates very slowly at normal temperatures; at $20^{\circ} \mathrm{C}$ the vapor pressure is $0.72 \mathrm{~mm}$ $\mathrm{Hg}$ [5]. The evaporated amounts are then sufficient to bring about a high saturation concentration (for example, $650 \mathrm{mg} / \mathrm{m}^{3}$ at $20^{\circ} \mathrm{C}$ ). At higher temperatures and little air movement, the danger of further enriching the air with 2-chlorodiethyl sulfide increases immensely. Because of its low vapor pressure, so-called fogs can persist in the air which possess certain adhesive properties. Such fogs show a strong tendency to remain stationary on terrain. In addition, its ability to penetrate through such materials as textiles, rubber, and leather is also strong. Heavy cow leather, for example, is penetrated in about 30 min. Wet clothes, including sweat-soaked uniforms, are equally permeable. The compound 2-chlorodiethyl sulfide is very easily soluble in acetone, ether, ethanol, gasoline, animal oils, and fats and is nearly insoluble in cold water $[2,7-10]$. 


\section{Clinical Findings of Mustard Gas Intoxication}

The picture of such a poisoning is characterized in the beginning by a latent period between contact and the first symptoms.

\section{Skin}

The local and systemic effects should be differentiated. Mustard gas penetrates the skin for 20 to 30 min without causing any warning signals, such as itching, burning, or sensations of wetness or cold. In relation to the exposure dose, exposure time, and aggregate state, the latent period varies between several hours and several days [11]. Certain regions of the body are particularly susceptible to skin damage because of their higher temperature, humidity level, sebaceous and sweat gland density, and relative thinness of the stratum corneum. Therefore, the vulnerable regions include the pubic area (particularly the scrotum), the underarms, the neck, the skin between the fingers and toes, and the area around the eyes $[2,7,9,12]$.

The skin damage can be differentiated into erythematous, superficial bullous, and deep bullous forms. The erythema appears approximately 6 to $8 \mathrm{~h}$ after contamination [5]. The skin becomes inflamed and reddens. If the contact was minimal, the poisoning remains at this stage and dissipates after about 1 week. If the contamination was more extreme, the erythematous form continues into the superficial bullous form. On the border of the erythema, blisters form, which merge towards the center to form larger ones. After 1 day, blister formation of the epidermis reaches its peak. This process is very painful. Serous fluid containing leukocytes, specifically eosinophils and lymphocytes, accumulates in the blisters. The necrotic epidermal tissue sloughs off after 1 week, and the granulating process starts at the border. Histologically, a heavy exudation of serum and erythrocytes is detected, originating from the greatly dilated blood vessels $[1,2,13]$. The collagen fibers of these vessels are found in a swollen state. Beginning around the vessels, inflammatory infiltrates show numerous eosinophils. After $12 \mathrm{~h}$, there is a vacuolation and a spongy dispersion of the epithelium which becomes increasingly prominent. The papillary dovetailing between the epidermis and the corium dissolves, the layers separate, and deep necrosis follows. In the following days the wound surface is surrounded by round cell infiltrates, which are most prevalent around the integumentary adnexae. Growth of new connective tissue during cicatrization is somewhat delayed.

If high concentrations of 2-chlorodiethyl sulfide have come into contact with the skin, the deep bullous form develops after 2 to $6 \mathrm{~h}$. It is characterized by the depth of the blisterous necrosis, which reaches the subcutis. This results in harmful ulcers, which heal very slowly and tend to become infected. If they do heal (after months), deep marginal pigmentation often develops $[2,14]$.

\section{Eyes}

Damage to the eyes is another highly feared effect. According to an American statistical study from the First World War [2] evaluating more than 7000 mustard gas victims, the eye was the most frequently damaged organ, rated at $86.1 \%$ (see Table 2 ). Many victims lost their eyesight because they rubbed their eyes with their hands, which had been contaminated with mustard gas [9]. As early as $2 \mathrm{~h}$ after contact (on the average, after 4 to $8 \mathrm{~h}$, the effects begin with a feeling as if sand grains were in one's eyes. A painful burning sensation follows, which leads to tearing. The eyelids swell to the point of closure. At the same time, the conjunctiva also swell $[15,16]$. The consequences include hypersensitivity to light and a lid cramp, resulting in a practical loss of vision. Usually the 
TABLE 2-Frequency distribution of more than 7000 cases of mustard gas injuries [2].

\begin{tabular}{lc}
\hline \multicolumn{1}{c}{ Site } & $\%$ \\
\hline Eyes & 86.1 \\
Respiratory tract & 75.3 \\
Scrotum & 42.1 \\
Face & 26.6 \\
Axilla & 12.5 \\
Arms & 11.7 \\
Legs & 11.4 \\
Abdominal region & 6.4 \\
Hands & 4.3 \\
Feet & 1.5 \\
\hline
\end{tabular}

cornea is also damaged; however, simple preliminary opacity is more common than necrosis. Only when the eyes have come in direct contact with the liquid form can necrosis and deep ulcers be observed [11].

\section{Respiratory Tract}

The most dangerous effects of mustard gas are manifested in the respiratory tract. The substance can be inhaled in droplet or vapor form. The damage is apparently concentration dependent; at low concentrations only the upper respiratory tract is affected. The latent period for respiratory tract damage is approximately 2 to $3 \mathrm{~h}$. The symptoms start with a lump sensation in the throat, followed by tickling and dryness, an urge to cough, difficulty in swallowing, and shortness of breath $[2,5,17]$. At the same time, the mucous membranes swell and develop an inflamed redness. In the next few days necrosis of the gums and mucous membranes occurs, and the lesions are covered with a greasy grayishyellow film. Fibrinous purulent pseudomembranes form in the trachea, similar to those seen in diphtheria. At higher inhaled concentrations the lower respiratory tract is also affected. After massive inhalation a serious, purulent, diphtheroid bronchitis develops, followed by pneumonia. This pneumonia may be localized, lobular, or gangrenous and is often hemorrhagic. In these serious cases, death often results when the pseudomembranes completely block the bronchial or tracheal passages, leading to suffocation. In rare cases when mustard gas reaches the alveoli, an acute, lethal lung edema may develop.

Two mortality peaks of the gas poisoning cases in Bari, Italy, have been determined: 48 people died 3 days after exposure, and 35 died 8 to 9 days after exposure [6]. The later deaths were due to the lung complications. Those who survived the lung effects often developed chronic spastic bronchitis and bronchiectasis.

A statistically significant increase in respiratory tract cancers was evident in workers of a Japanese mustard gas factory $[18,19]$. The carcinogenic action of this substance has also been confirmed in animal experiments [20].

\section{Other Organs}

Mustard gas also affects a number of other organs and tissues because of its high solubility in lipids. Therefore, several unspecific, general symptoms follow, such as nausea, vomiting, abdominal pains, headache, fatigue, apathy, diarrhea, weight loss, and tachycardia [15]. The majority of these symptoms are apparently caused by damage to the gastrointestinal tract $[4,12,21]$. Also they are partly explained by the substance's effect on the hematopoietic system. In animal experiments, nuclear dissociation of lym- 
TABLE 3-Effects of mustard gas on humans.

\begin{tabular}{ccl}
\hline Concentration, ppm & Duration, min & \multicolumn{1}{c}{ Effects } \\
\hline 0.1 & 10 & first damages (eyes, skin) \\
1.0 & 60 & serious lung damages \\
10 & 60 & dangerous to life \\
100 & 10 & lethal within a few hours \\
\hline
\end{tabular}

phocytes followed by necrosis has been determined in spleen and lymph nodes $[4,22]$. A release of lymphocytes into the bloodstream has also been observed. In such cases, lymphocyte-producing organs such as the spleen shrink notably $[23,24]$. Whereas regenerative processes begin after a few days in the spleen, the bone marrow reacts to mustard gas more slowly and also regenerates more slowly. Leukopoietic cells have proved to be especially susceptible, while the hematopoietic cells are relatively resistant. Leukopenia has been detected in the circulating blood, more specifically, lymphophenia followed by a reduction of the granulocytes. These findings in animal experiments have not, however, been observed in humans as often as the opposite reaction, that is, long-lasting hyperplasia [2]. Agranulocytosis has occurred only in cases of severe poisoning. The red cell count often showed only a minor to moderate hemoglobin deficiency, accompanied by hemosiderosis in the spleen and liver $[2,4]$. The reaction of thrombocytes differed. Cases of low thrombocyte count occurred alongside those with no reaction at all $[12,23]$. An increased coagulation ability following severe poisonings has been described in several accounts in the medical literature; however, sedimentation rates differ $[2,25]$. The literature indicates virtually no morphological heart effects. Nevertheless, slight, reversible electrocardiogram (EKG) irregularities have been seen in humans $[14,26]$. Because of the severe local edema, the circulatory function is also adversely affected. This is expressed by a decrease of the plasma volume (including plasma proteins), which thus increases the blood viscosity $[6,27,28]$.

To conclude a review of these effects, various other organs warrant mentioning. Both enlargements and atrophies of the liver have been observed [6]. Histological findings in animal experiments include cloudy swelling, fatty degeneration, a decrease in glycogen, and necrosis of the liver cells, as well as hemosiderosis and fatty degeneration of the Kupffer cells [29]. The kidneys react with hyperemia, bleeding, cloudy swelling of the tubular epithelium, and the presence of hemoglobin casts and sclerotic casts in the distal tubules $[4,29]$.

Surprisingly, the morphological effects on the central nervous system (CNS) are minimal, although severe apathy and general indifference are typically reported as chronic consequences of mustard gas poisoning $[15,30]$.

\section{Clinical and Morphological Findings for the Patients Treated in Munich, 1984-1985}

In 1984 and 1985, a total of eleven patients from Iran were transferred to hospitals in Munich, Germany. One patient died on the third day after admission; the others were discharged to return home after 5 to 7 weeks in improved condition. Since follow-up examinations were not carried out, no comment can be made about the long-term consequences. All the victims reported that they had been stationed on the island of Madjun in the Persian Gulf when attacked with the gas. They described a bomb release in which smoke or dust escaped after the detonation. Some described the cloud as dry and white, others as moist and grayish-white. These differences in the descriptions could depend on the possibly differing carrier substances used. The soldiers were not prepared for an 
attack involving gas, and when they sensed a smell of garlic or vegetables fried in oil, they still did not take any protective measure.

\section{First Symptoms and Pretreatment at Teheran}

Two soldiers experienced burning of the eyes after only $5 \mathrm{~min}$, although in most cases this occurred after $1 / 2$ to $2 \mathrm{~h}$, along with a sensation of a foreign body in the eyes, shortness of breath, and even a burning of the skin. Several experienced nausea, abdominal pains, dizziness, weakness, a sore throat, and difficulty in swallowing. After 3 to $4 \mathrm{~h}$ their eyes became swollen to the point of closure, and at this time vomiting started. These symptoms increased in the next few hours, in addition to coughing, dyspnea, headache, and fatigue. Redness, swelling, and blistering of the skin followed; in one case, greater areas of the skin peeled off. Several became somnolent or completely unconscious.

The soldiers were taken to hospitals in Teheran on the day of the attack or the following day. The following symptoms were recorded in the first days: moderate elevation of temperature, somnolence, weakness, dyspnea, hoarseness, difficulty in swallowing, conjunctivitis, blistering of the skin, and a yellow phlegm of gelatinous consistency.

\section{Results of the Admittance Examinations}

The patients were transported to Germany 4 to 6 days after exposure, in one case, 17 days after exposure. Upon admission, the following results were determined by examination: all the patients suffered from conjunctivitis, some with heavy secretions and an isolated few with erosions and slight opacity of the cornea. The redness and blister formation of the skin resembled first- and second-degree burns and was accompanied by pain and itching. The most severely affected areas included the face, arms, thorax, and genitals. Serious damage to the respiratory tract was determined by bronchoscopy. In most cases, respiratory tract injury developed further during the hospital stay. The most frequent findings were redness, swelling, and edema of the mucous membranes; petechial bleeding and fibrin depositions; and, in some cases, necrotic appositions in the tracheal area. Coughing attacks and dyspnea frequently followed when parts of the mucous membranes loosened. For the most part, the lungs were clear on auscultation. In the beginning, the average body temperature was 38 to $38.5^{\circ} \mathrm{C}$. A few patients complained of diffuse abdominal pains, and they suffered more from obstipation than from diarrhea.

\section{Clinical Course}

The most serious respiratory tract alterations occurred 8 to 10 days after admittance (or 14 days after exposure). The deep necrosis and membrane-like fibrin appositions were so severe in three patients that tracheotomy was necessary. X-rays showed evidence of short-term pneumonic alterations in four cases. Blisters of the skin turned into greasy appositions and incrustations, which in some cases became infected. Between the 13th and 20th day after exposure, sepsis occurred in three patients, accompanied by a fever up to $40.4^{\circ} \mathrm{C}$. The cardiac functions, blood pressure, pulse rate, and EKG values were stable. In contrast, all the patients were more or less somnolent and apathetic at admittance; one patient even presented symptoms of psychosis. These symptoms did, however, subside after 1 week.

\section{Clinical Laboratory Data}

The laboratory data were of particular interest. Within the first 14 days after exposure, leukocytosis developed (approximately 10 to $11000 / \mathrm{cu} \mathrm{mm}$ ), which returned to normal 
values 24 days after exposure, although isolated cases of granulocytopenia were found even later. The white blood cell (WBC) profile showed a left shift to juvenile forms, with relative lymphopenia; toxic granulations were often present. All the cases showed a definite increase of the erythrocyte sedimentation rate, with a maximum at the $23 \mathrm{rd}$ or 24th day after exposure (AE), which began to decrease only after 3 to 4 weeks. As evidence of renal damage, the complement ratio, $\mathrm{C} 3 \mathrm{c}$, and alpha-1-antitrypsin were increased in only half of the patients. A distinct increase of fibrinogen occurred 14 to 17 days $\mathrm{AE}$, up to twice the normal values. Electrophoresis showed dysproteinemia 14 to 17 days $\mathrm{AE}$, with a reduction of albumin and an increase of alpha-1, alpha-2, and gamma globulins. Examination of immunoglobulins consistently showed an increase in immunoglobin $\mathrm{E}$ ( $\mathrm{IgE}$ ) values, but normal immunoglobin $\mathrm{A}$ and $\mathrm{M}$ (IgA and $\operatorname{IgM}$ ) values.

The liver values were not altered as much as expected. The mean values of glutamic pyruvic transaminase (GPT) 10 to 12 days AE were approximately 22 units (U)/L and showed another similar increase 24 to 28 days AE, with a peak of $142 \mathrm{U} / \mathrm{L}$. A more distinct increase was seen in the gamma glutamic transaminase, which rose 10 to 19 days $\mathrm{AE}$ to a mean of $118 \mathrm{U} / \mathrm{L}$ and a maximum of $199 \mathrm{U} / \mathrm{L}$.

Alkaline phosphatase showed no similar increase in the early phase. Ten to 14 days AE, some patients showed increased alkaline phosphatase (maximum, about $252 \mathrm{U} / \mathrm{L}$ ). After 32 days $\mathrm{AE}$, the mean values were above normal.

Cholinesterase values were diminished, which confirms clinical experience that mustard gas poisoning elicits some of the same reactions seen with phophorus acid ester intoxication. Four to 32 days $\mathrm{AE}$, the mean minimum value was $2379 \mathrm{U} / \mathrm{L}$; the lowest single value was $1864 \mathrm{U} / \mathrm{L}$.

A decrease in hemoglobin was evident in all patients even 4 to 14 days $\mathrm{AE}(<10 \mathrm{~g} /$ $\mathrm{dL}$ ), and this trend continued up to the third week. The red blood cell (RBC) count decreased to a minimum of $2.8 \times 10^{8} / \mathrm{mL}$ and normalized only after the fourth week. Between the first and the second week AE, coagulation factors VIII and IX increased, while factors II, VII, and X decreased. A common reaction of thrombocytes was not evident; the count was decreased in half of the patients and increased in the other half. By the 14th day AE, the values of cases with a primary decrease had increased to a mean maximum of $341.500 / \mathrm{cu} \mathrm{cm}$. Normal laboratory parameters were found for the serum urea, creatinine and electrolytes, uric acid, bilirubin, triglycerides and cholesterol, and also inorganic phosphorus, creatinine kinase, and lipase. The liquid balance was in equilibrium in most cases.

Ten to 14 days AE, electroencephalogram tests depicted minimal to medium-grade general changes with dominant teta waves, which disappeared after 6 weeks. Bone marrow biopsies showed reactive changes of granulopoiesis and erythropoiesis 10 to 30 days AE. In the beginning, the granulocyte count increased, while the lymphocyte count decreased, but after 30 days, the opposite occurred. When erythropoiesis increased, simultaneous disturbances of megakaryocytosis and signs of pigment loss were present. The peripheral blood profile showed corresponding changes.

The body temperature rose to a mean of 38 to $38.5^{\circ} \mathrm{C}$ and normalized in the third week. Healing of the skin injuries began in the third week and was slowly completed within the following 2 months. The remaining lesions includes isolated corneal opacities, hyperpigmentation on the edges of skin lesions, and contractures due to cicatrization.

\section{The Mortal Case}

\section{Course and Clinical Laboratory Data}

The course and outcome for one 24-year-old soldier, P. R., was different. He was admitted to the Klinikum Rechts der Isar in Munich 5 days after exposure in a state of 
severely clouded consciousness. He was suffering from serious exfoliative and bullous skin lesions.

Laboratory test values showed some elevations in compared with normal values, for example: urea, $54 \mathrm{mg} / \mathrm{dL}$; creatinine, $15 \mathrm{mg} / \mathrm{dL}$; total bilirubin, $1.5 \mathrm{mg} / \mathrm{dL}$; creatinine kinase, $469 \mathrm{U} / \mathrm{L}$; uric acid, $14.4 \mathrm{mg} / \mathrm{dL}$; and lactate dehydrogenase; $566 \mathrm{U} / \mathrm{L}$. At the same time, his cholinesterase dropped to $2900 \mathrm{U} / \mathrm{L}$. The blood profile showed no irregularities at first. In the first few hours after admittance, the kidney function improved, but then a sharp drop in the leukocyte and thrombocyte counts occurred, with values of 3100 / $\mathrm{mm}^{3}$ and $50000 / \mathrm{mm}^{3}$, respectively. On the second day of hospital stay, his body temperature rose to over $39^{\circ} \mathrm{C}$. In the evening of this day, the WBC was approximately $250 /$ $\mathrm{mm}^{3}$ and the thrombocyte count was $17000 / \mathrm{mm}^{3}$. In the beginning, the patient presented symptoms and venous blood gases consistent with pharyngolaryngitis, but increasing difficulty in breathing came about during the night of the second and third days of treatment. His temperature rose to $40.4^{\circ} \mathrm{C}$. In the morning of the third day of treatment, the patient suddenly stopped breathing. Despite immediate intubation, breathing could not be restored. During an emergency bronchoscopy, a large piece of mucous membrane blocking a bronchus was removed, but resuscitation efforts were nevertheless unsuccessful.

\section{Autopsy Findings}

The most important autopsy findings were severe pseudomembranous inflammation of the trachea and bronchial tubes and localized pneumonia. Characteristic blisters of the skin, accompanied by blackish-brown pigmentation, were evident in various body regions, especially on the neck, arms, forehead, and genital area. The mucous membranes of the lips, gums, and tonsillar ring were covered with a film and blood. The eyes exhibited slit-like hemorrhages of the sclera and opacity of the cornea. A membranous film covered the inside of the ascending colon. Cloudy swelling of the myocardium, liver, and kidneys, as well as a definitive enlargement of the spleen and lymph nodes were present. A recent endocarditis of the mitral valve was also evident.

\section{Histology}

Pathological changes of varying degrees were determined in the histological examination. The brain, for example, exhibited little change except for nonspecific edema. Particularly notable changes were found in the examination of the trachea. Pseudomembranous layers of fibrin and inflammatory cells obstructed the excretory ducts of the mucous glands. Blockage by mucus occurred, followed by necrosis. This offers an explanation for the difficulty of breathing and chronic bronchitis described in the medical literature. Spongiform lesions of the epidermis, accompanied in part by a separation of the corium and blister formation, were seen. The contents of the blisters consisted of a fibrin net with granulocytes. Perivascular round cell infiltrates, described in the medical literature, were not found to the extent expected, possibly because of the medical treatment. Collagen fibers were found in a swollen state, along with completely effaced papillae, where the cells of the stratum basale often showed blisterous swelling.

The bone marrow showed conspicuously extensive losses of myeloid stem cells and megakaryocytes. In contrast, the sinus contained a heavy congestion of blood and plasma cells. The loss of lymphocytes in the lymph nodes and spleen was so serious that only the germinal centers of the follicles could be distinguished.

Findings such as those determined here have also been observed in animal experiments with rabbits [3] and guinea pigs [1] between the two world wars, but not in every case in humans. 
With regard to the variable clinical picture, the chemical proof of the poison [31] was of particular importance because Iraq had denied the use of mustard gas and because other chemical weapons were under suspicion as the cause of the injuries.

\section{References}

[1] Richter, W., "Kampfstoffwirkung und Heilung," Wehr und Wissenschaft, Vol. 26, 2nd ed., Ambrosius Barth, Leipzig, Germany, 1941.

[2] Muntsch, O., Leiffaden der Pathologie und Therapie der Kampfstofferkrankungen, Georg Thieme, Leipzig, Germany, 1944.

[3] Hanslian, R., Der Chemische Krieg, 2nd ed., Mittler und Sohn, Berlin, 1927.

[4] Merkel, H., "Effect of Dichloroethyl Sulfide on Blood and Haemopoietic Tissues: Experimental Studies," Zentralblatt der Allgemeinen Pathologie, Vol. 87, 1951, p. 76.

[5] Klimmek, R., Szinicz, L., and Weger, N., Chemische Gifte und Kampfstoffe: Wirkung und Therapie, Hippokrates, Stuttgart, Germany, 1983.

[6] Alexander, S. F., "Medical Report of the Bari Harbor Mustard Casualties," Military Surgeon, Vol. 101, 1947, pp. 1-17.

[7] Davis, J., "Dermatologic Aspects of Vesicant War Gas (Dichloroethyl Sulfide and Dichlorovinylarsine)," Journal of the American Medical Association, Vol. 126, 1944, p. 209.

[8] Dickel, H., Fincke, A., and Gohr, H., "Poisoning of Workers Due to Dichloroethyl Sulfide," Die Medizinische, 1952, p. 686.

[9] Gilbert, E., "Die Kampfstofferkrankungen (Erkennung, Verlauf und Behandlung der durch chemische Kampfstoffe verursachten Schäden)," Urban und Schwarzenberg, Berlin-Wien, Berlin, 1939.

[10] Renshew, B., "Observations on the Role of Water in the Susceptibility of Human Skin to Injury by Vesicant Vapors," Journal of Investigative Dermatology, Vol. 9, 1947, p. 75

[11] Flury, F. and Willand H., "Über Kampfgasvergiftungen: VII. Die pharmakologische Wirkung des Dichlordiäthylsulfids (Thiodiglycolchlorid, Gelbkreuzstoff, Senfgas, Yperit, Lost)," Zeitschrift für die Gesamte Experimentelle Medizin, Vol. 13, 1921, p. 367.

[12] Sinclair, D. C., "The Clinical Reaction of the Skin to Mustard Gas Vapor," British Journal of Dermatology, Vol. 61, 1949, p. 113.

[13] McAdams, A. J. J., "A Study of Mustard Vesication," Journal of Investigative Dermatology, Vol. 26, 1956, p. 317.

[14] Gohlke, H. and Ullerich, K., "Cutaneous and Ocular Lesions Caused by Dichloroethyl Sulfide," Hautarzt, Vol. 2, 1951, p. 404.

[15] Müller, U., "Eigenschaften und Wirkungsweise von Lost," inaugural dissertation, Friedrich Alexander University, Erlangen, Germany, 1971.

[16] Uhde, G. J., "Mustard Gas (Dichloroethyl Sulfide) Burns of Human Eyes in World War II," American Journal of Ophthalmology, Vol. 29, 1946, p. 929.

[17] Iwaszkiewicz, J., "Burns of the Upper Respiratory Tract Due to Mustard Gas," Otolaryngologia Polska, Vol. 20, 1966, p. 237.

[18] Wada, S., "Mustard Gas as a Cause of Respiratory Neoplasia in Man," The Lancet, Vol. 1, 1968 , p. 1161.

[19] Yamada, A., "On the Late Injuries Following Occupational Inhalation of Mustard Gas with Special References to Carcinoma of the Respiratory Tract," Acta Pathologica Japonica, Vol. 13,1963 , p. 131.

[20] Hueper, W. C., "Symposium on Chemical Carcinogenesis: Part I-Environmental and Occupational Cancer Hazards," Clinical Pharmacology and Therapy, Vol. 3, 1962, p. 776.

[21] Collumbine, H., "Medical Aspects of Mustard Gas (Dichloroethyl Sulfide) Poisoning," Nature, Vol. 159, 1947, p. 151.

[22] Kindred, J. E., "Histologic Changes Occurring in the Hemopoietic Organs of Albino Rats After Single Injections of 2-Chloroethyl Vesicants: A Quantitative Study," Archives of Pathology, Vol. 43, 1947, p. 253.

[23] Graef, J., Karnofsky, D. A., Jager, V. B., Krickesky, B., and Smith, H. W., "The Clinical and Pathological Effects of the Nitrogen and Sulfur Mustards in Laboratory Animals," American Journal of Pathology, Vol. 24, 1948, p. 1.

[24] Karnofsky, D. A. and Graef, J., "Studies on the Mechanism of Action of Nitrogen and Sulfur Mustards in Vivo," American Journal of Pathology, Vol. 24, 1948, p. 275.

[25] Aschoff, L., "Über anatomische und histologische Befunde bei 'Gasvergiftungen'," Kriegsministerielle Druckschrift, Reichsdruckerei, Berlin, 1916.

[26] Menzel, W. and Willhoeft, J., "Hyperplastic Late Reaction of Hemopoietic Organs Following Dichloroethyl Sulfide Poisoning," Folia Haematologica, Vol. 70, 1951, p. 278. 
[27] Black, S. and Thomson, J. F., "Metabolic Effects Produced by Large Doses of Di- $\beta$-Chloroethyl Sulfide in Rats," Journal of Biological Chemistry, Vol. 167, 1947, pp. 283-289.

[28] Cameron, G. R. and Courtice, F. C., "Effects of Skin Contamination with Liquid Mustard on Water Balance in Animals," Quarterly Journal of Experimental Physiology, Vol. 34, 1948, p. 165.

[29] Rothlin, E., "Cause of Poisoning with Phosgen and Dichloroethyl Sulfide, Results of Animal Experiments," Schweizer Medizinische Wochenschrift, Vol. 73, 1943, p. 1205.

[30] Henlly, F., "Mass Intoxication Due to Explosion of a Shell Containing Dichloroethyl Sulfide Dating Back to World War I," Annales de Médicine Légale, Vol. 36, 1956, p. 195.

[31] Drasch, G., Kretschmer, E., Kauert, G., and von Meyer, L., "Concentrations of Mustard Gas [Bis(2-Chloroethyl) Sulfide] in the Tissues of a Victim of a Vesicant Exposure," Journal of Forensic Science, Vol. 32, No. 6, Nov. 1987, pp. 1788-1793.

Address requests for reprints or additional information to

Prof. Gustav Drasch

Forensic Toxicology

Institut für Rechtsmedizin

Frauenlobstrasse $7 \mathrm{a}$

8000 Munich 2

Germany 